\title{
Genetic relationships among landlocked, resident, and anadromous Brown Trout, Salmo trutta L.
}

\author{
K. HINDAR, B. JONSSON, N. RYMAN* \& G. STÄHL* \\ Norwegian Institute for Nature Research, Tungasletta 2, N-7004 Trondheim, Norway and *Department of Genetics, \\ University of Stockholm, S-106 91 Stockholm, Sweden
}

\begin{abstract}
Coexisting freshwater resident and anadromous (sea-run migratory) Brown Trout, Salmo trutta L., were compared genetically with landlocked populations (i.e. living above impassable waterfalls) in the same drainage system in western Norway. No genetic differentiation was found between resident and anadromous life-history types using the same locality and time for spawning. In contrast, significant genetic differences were found between Brown Trout (irrespective of lifehistory type) spawning in geographically separate localities, and particularly large differences were found between landlocked Brown Trout and those from localities accessible from the sea. These results are consistent with other multiple-locus studies of salmonid fishes, showing larger genetic differentiation between localities than between coexisting life-history types that differ in morphology and ecology.
\end{abstract}

Keywords: life-history polymorphism, population genetics, protein electrophoresis, Salmonidae.

\section{Introduction}

A number of salmonid species contain ecologically and morphologically different types whose evolutionary relationships remain uncertain (Behnke, 1972; Balon, 1980). Anadromous (sea-run migratory) individuals commonly coexist with individuals maturing sexually in fresh water without having been to sea (Ricker, 1972; Scott \& Crossman, 1973). When this variable lifehistory pattern occurs only in one sex, as in male Atlantic Salmon, Salmo salar L., and Chinook Salmon, Oncorhynchus tshawytscha (Walbaum), no confusion about genetic relationships arises. But when both sexes commonly show coexisting freshwater resident and anadromous individuals, as in Brown Trout, $S$. trutta L., Arctic Charr, Salvelinus alpinus (L.), Sockeye Salmon, O. nerka (Walbaum), and Rainbow Trout, $O$. mykiss (Walbaum), the coexisting life-history types may (or may not) represent separate, genetically divergent populations.

Further confusion has arisen by the natural occurrence of entirely freshwater resident populations where access from the sea has been cut off (Ricker, 1972). These populations (herein referred to as 'landlocked' in order to distinguish them from freshwater resident individuals in 'accessible' localities) were long recog- nized as separate sub-species, e.g. lacustrine Brown Trout, S. trutta lacustris, and Kokanee Salmon, $O$. nerka kennerlyi. Morphologically, landlocked individuals often resemble the resident life-history type (Fig. 1), but large lakes and rivers may have freshwater migratory types that resemble the anadromous type both in morphology and migration patterns (Krueger \& May, 1987).

Landlocked salmonid populations that have been studied appear to have been derived from previously existing anadromous populations in the same localities based on the small genetic differences observed from anadromous populations in the same region. Such a relationship has been established for Rainbow Trout (Allendorf \& Utter, 1979), Brown Trout (Ryman, 1983), Cutthroat Trout, O. clarki (Walbaum) (Campton \& Utter, 1987), Atlantic Salmon (Ståhl, 1987), and Sockeye Salmon (Foote et al., 1989), and probably also holds true for Arctic Charr, although data on anadromous Arctic Charr are so far limited (Kornfield et al., 1981; Hindar et al., 1986).

On the other hand, the amount of genetic differentiation between coexisting resident and anadromous types has yet to be established for most salmonid species (Foote et al., 1989). For example, the conclusions of recent studies reporting significant genetic dif- 


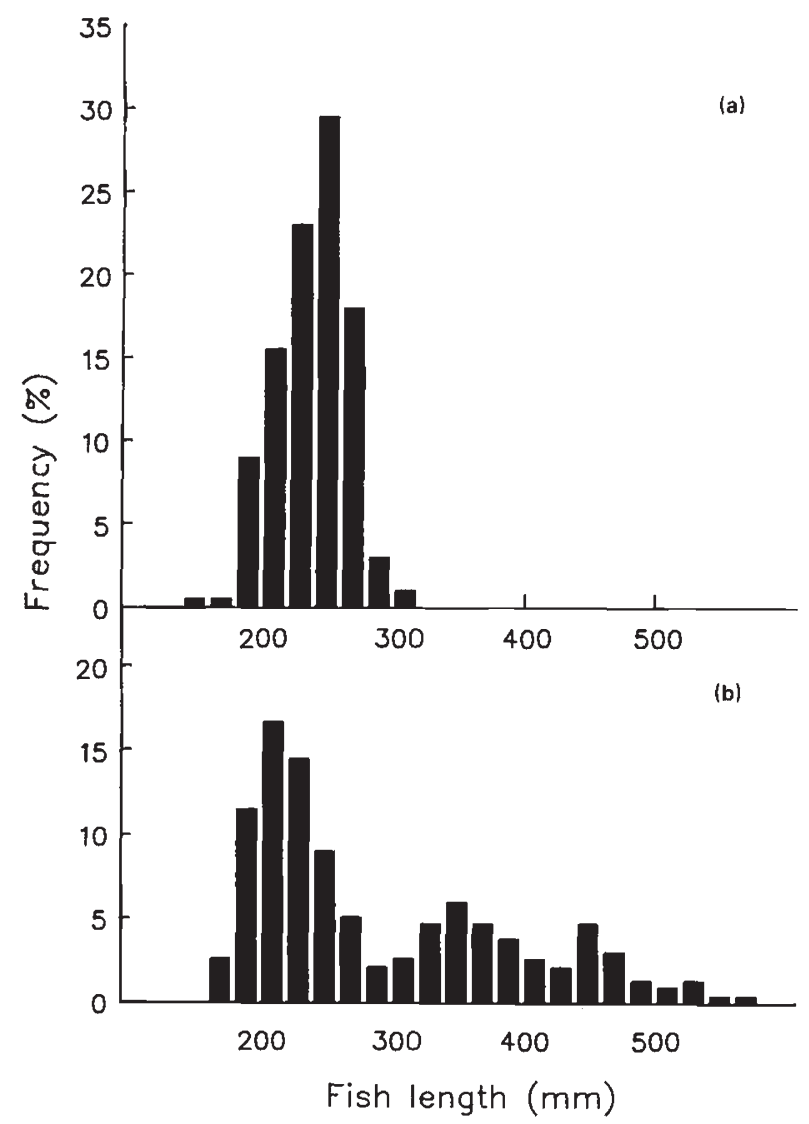

Fig. 1 Length frequency distribution of sexually mature Brown Trout from the Voss River System, Norway. (a) Landlocked Brown Trout $(N=200)$. (b) Coexisting freshwater resident and anadromous Brown Trout, corresponding to the left and right modes, respectively, of the length distribution $(N=234)$.

ferences between resident and freshwater migratory Brown Trout (Krueger \& May, 1987), and between resident and anadromous Brown Trout (Skaala \& Nævdal, 1989), may be questioned on the basis of sampling strategy, because resident and migratory individuals were collected from different localities within the same drainage system. Thereby, the possibility cannot be ruled out that the genetic differences reported between resident and migratory Brown Trout reflect differences between local populations rather than differences between life-history types (Krueger \& May, 1987). To settle this matter it is necessary to study resident and anadromous individuals from the same spawning localities to establish whether the different life-history types belong to the same population or not.

Here we address the following questions: (1) how divergent are resident and anadromous Brown Trout spawning in the same locality, and (2) to what extent do life-history characteristics reflect the amount and distribution of genetic variation in Brown Trout from the same watercourse? Brown Trout was chosen because resident, anadromous and landlocked types can be found within a single drainage system (Jonsson, 1989; and references therein), and because the geographical population structure of Brown Trout is well known from extensive genetic studies (reviewed by Ryman, 1983; Ferguson, 1989). We discuss our findings in relation to the parallel evolution of different lifehistory types within a number of salmonid fishes (e.g. Behnke, 1972).

\section{Materials and methods}

Brown Trout were collected by electrofishing in five study sites (A-E) in the Voss River system, western Norway (Fig. 2). Of 474 individuals collected, 434 were adult Brown Trout caught during the spawning seasons (October) of 1980 (sites D and E) and 1981 (sites A-D), and 40 were juvenile Brown Trout (parr) from site D, caught on 5th August 1980 (Table 1).

Landlocked Brown Trout are the only fish present in study sites A, B and C, being prevented from diadromous migration by an impassable waterfall further downstream (Fig. 2). Site A (Fiksno River) is the major spawning tributary for the landlocked Brown Trout of Lake Myrkdalsvatnet. Sites B (Gryteelvi River) and C (Langejolo River) are major spawning tributaries for the landlocked Brown Trout of Lake Oppheimsvatnet. These study sites are recolonized every year for feeding and spawning, and no fish overwinter in them. The observed straying rate of repeat spawners in Lake Oppheimsvatnet (between sites B and C and four other tributaries of that lake) is $\sim 7$ per cent $(\mathrm{K}$. Hindar \& B. Jonsson, unpublished results).

Resident and anadromous Brown Trout coexist in study sites D (Dyrvo River) and E (Teigdalselvi River), which are tributaries of Lake Vangsvatnet and Lake Evangervatnet, respectively (Fig. 2). Our samples of resident and anadromous Brown Trout from Dyrvo River (D) represent all spawners present in the spawning area on the sampling dates. The sample from Teigdalselvi River (E) represents all the spawners we were able to catch during one day on various river stretches from 1 to $5 \mathrm{~km}$ above Lake Evangervatnet. No fish overwinter in Dyrvo River (D), which is recolonized in the spring by parr and resident Brown Trout for feeding, and in the fall by anadromous and resident Brown Trout for spawning. Teigdalselvi River (E) probably holds fish throughout the year.

Each spawner from study sites D and E was classified as either the resident or anadromous type on the basis of scale characters (Frost \& Brown, 1967; Jonsson, 1985). All spawners were aged and sexed and 
Fig. 2 Location of the study sites in the Voss River system, Norway. Map codes are: $A=$ Fiksno River, $B=$ Gryteelvi River, $\mathrm{C}=$ Langejolo River, $\mathrm{D}=$ Dyrvo River, and $\mathrm{E}=$ Teigdalselvi River. $\mathrm{A}$ horizontal bar denotes the position of an impassable waterfall above which all Brown Trout are landlocked.

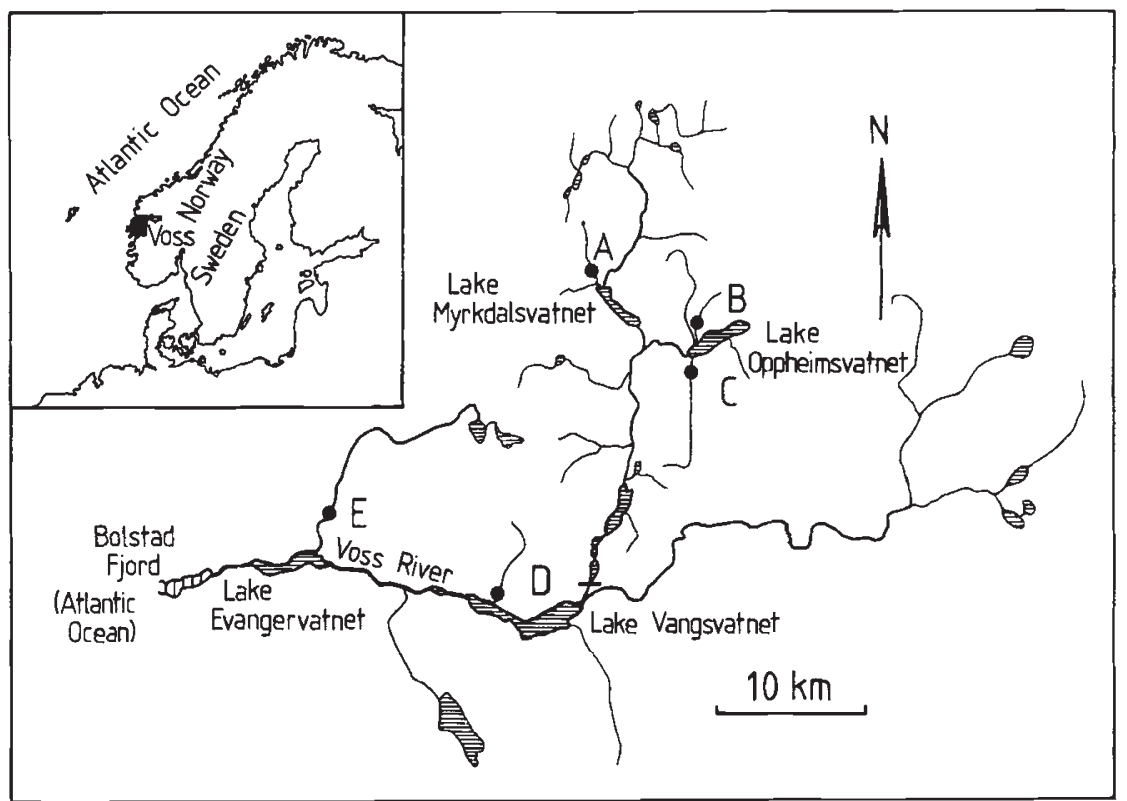

Table 1 Sampling information for Brown Trout collected in the Voss River system, Norway, during 1980-1981. $N=$ number of fish, $\mathrm{L}=$ landlocked, $\mathrm{P}=$ parr, $\mathrm{R}=$ resident, $\mathrm{A}=$ anadromous, $\mathrm{F}=$ female, $\mathrm{M}=$ male,$-=$ no data. All fish were caught as spawners on the spawning grounds, except for the parr, which are immature fish, using the same river stretch (site D) for feeding. Map codes refer to Fig. 2

\begin{tabular}{|c|c|c|c|c|c|c|c|c|c|}
\hline \multirow[b]{2}{*}{$\begin{array}{l}\text { Map } \\
\text { code }\end{array}$} & \multirow[b]{2}{*}{ Lake } & \multirow[b]{2}{*}{ Tributary } & \multirow[b]{2}{*}{ Morph } & \multirow[b]{2}{*}{ Sex } & \multirow[b]{2}{*}{$N$} & \multicolumn{2}{|c|}{$\begin{array}{l}\text { Fish length } \\
(\mathrm{mm})\end{array}$} & \multicolumn{2}{|c|}{ Age (years) } \\
\hline & & & & & & $\bar{x}$ & s.d. & $\bar{x}$ & s.d. \\
\hline A & Myrkdalsvatnet & Fiksno & $\mathrm{L}$ & $\mathrm{F}$ & 18 & 259 & 25 & 6.5 & 2.2 \\
\hline A & Myrkdalsvatnet & Fiksno & $\mathrm{L}$ & M & 82 & 229 & 26 & 5.0 & 1.6 \\
\hline B & Oppheimsvatnet & Gryteelvi & $\mathrm{L}$ & $\mathrm{F}$ & 22 & 251 & 17 & 5.1 & 1.6 \\
\hline B & Oppheimsvatnet & Gryteelvi & $\mathrm{L}$ & $\mathbf{M}$ & 28 & 240 & 25 & 4.4 & 2.0 \\
\hline $\mathrm{C}$ & Oppheimsvatnet & Langejolo & $\mathrm{L}$ & $\mathrm{F}$ & 11 & 257 & 12 & 5.1 & 1.3 \\
\hline $\mathrm{C}$ & Oppheimsvatnet & Langejolo & $\mathrm{L}$ & $\mathbf{M}$ & 39 & 244 & 27 & 4.5 & 1.6 \\
\hline D & Vangsvatnet & Dyrvo & $\mathrm{P}$ & - & 40 & 87 & 31 & - & - \\
\hline D & Vangsvatnet & Dyrvo & $\mathbf{R}$ & $\mathrm{F}$ & 3 & 260 & 21 & 5.7 & 0.6 \\
\hline D & Vangsvatnet & Dyrvo & $\mathbf{R}$ & $\mathbf{M}$ & 104 & 229 & 39 & 3.9 & 1.6 \\
\hline D & Vangsvatnet & Dyrvo & A & $\mathrm{F}$ & 17 & 448 & 55 & 5.4 & 0.9 \\
\hline $\mathrm{D}$ & Vangsvatnet & Dyrvo & A & $\mathbf{M}$ & 48 & 392 & 70 & 4.7 & 1.3 \\
\hline $\mathrm{E}$ & Evangervatnet & Teigdalselvi & $\mathbf{R}$ & $\mathbf{M}$ & 42 & 228 & 35 & 6.6 & 1.5 \\
\hline $\mathrm{E}$ & Evangervatnet & Teigdalselvi & A & $\mathrm{F}$ & 10 & 413 & 42 & 5.5 & 0.7 \\
\hline $\mathrm{E}$ & Evangervatnet & Teigdalselvi & A & M & 10 & 392 & 64 & 5.2 & 0.6 \\
\hline
\end{tabular}

their natural tip lengths measured to the nearest $0.1 \mathrm{~cm}$ (see Jonsson, 1985 for methods). The parr from Dyrvo River (D) were not aged or sexed. Length variation among sexes, spawning sites and life-history types were studied using a nested analysis of variance as described by Sokal \& Rohlf (1981; NESTAN program).
Tissue samples of skeletal muscle, liver and eye were stored at $-80^{\circ} \mathrm{C}$ until required for biochemical analysis. Horizontal starch gel electrophoresis was performed as described by Utter et al. (1974). The buffer systems used, the proteins examined, and the genetic interpretations of the electrophoretic banding patterns 
are those of Allendorf et al. (1977). We designate loci, alleles and genotypes according to the nomenclature proposed by Allendorf \& Utter (1979). Variant alleles are designated according to their electrophoretic mobility relative to the common $(100)$ allele.

We scored the gene products of the following 40 loci: aspartate aminotransferase (Aat-1, Aat-2, Aat-3), alcohol dehydrogenase $(A d h), \alpha$-glycerophosphate dehydrogenase $(A g p-2)$, adenylate kinase $(A k-3)$, creatine phosphokinase $(C p k-1, C p k-2\rangle$, diaphorase (Dia), esterase (Est-2), glyceraldehyde-3-phosphate dehydrogenase (Gapdh-1, Gapdh-2), glutamate dehydrogenase $(G d h), \beta$-glucuronidase (Gus), glucose6-phosphate dehydrogenase (G6pdh-1), hexokinase (Hk-1), isocitrate dehydrogenase $(I d h-1, I d h-2)$, lactate dehydrogenase ( $L d h-1, L d h-2, L d h-3, L d h-4, L d h-5)$, malic enzyme (Me-1, Me-2, Me-3), malate dehydrogenase (Mdh-1, $M d h-2, M d h-3, M d h-4)$, phosphoglucose isomerase (Pgi-1, Pgi-2, Pgi-3), phosphoglucomutase (Pgm-1, Pgm-2), phosphomannose isomerase (Pmi), 6-phosphogluconate dehydrogenase (6-Pgdh), sorbitol dehydrogenase $(S d h-2)$, superoxide dismutase $(S o d)$ and xanthine dehydrogenase $(X d h)$. Descriptions of electrophoretic variability patterns for these isozymes are given by Allendorf et al. (1977), Taggart et al. (1981) and Ferguson (1989); inheritance studies confirming a genetic basis for their variation are summarized by Ferguson (1989).

Allele frequencies were estimated by direct allele counts. Tests for allele frequency homogeneity were performed using the $G$ statistic described by Sokal \& Rohlf (1981). Pairwise standard genetic distance values were calculated according to $\mathrm{Nei}(1975)$, and a dendrogram was constructed from those values using the unweighted pair-group method of arithmetic averages
(UPGMA; Sneath \& Sokal, 1973). The proportion of the total genetic variation attributable to differences among the various life-history types and local populations was estimated by a hierarchical gene diversity analysis (Nei, 1975; Chakraborty et al., 1982).

\section{Results}

Genetic variation was found at the following six loci; the alleles observed are given in parentheses: Aat-3 (100 and 50), Agp-2 (100, 50 and 25), Cpk-1 (100 and 115), Ldh-5 (100 and 105), Mdh-2 (100 and 125), and Pgi-2 (100 and 130). The variant alleles observed are presented in Table 2 along with their frequencies. Samples from different years (1980 and 1981) at site D were pooled because no allele frequency differences were found between years in either the resident or the anadromous Brown Trout (other sites were sampled only one year).

The average heterozygosities are within the range of those usually reported for Brown Trout (e.g. Ryman, 1983; Ferguson, 1989). They were higher among resident and anadromous Brown Trout $(\sim 3$ per cent at sites $\mathrm{D}$ and $\mathrm{E}$ ) than among the landlocked Brown Trout ( $\sim 1$ per cent or less at sites A, B and C; Table 2).

Significant deviation from Hardy-Weinberg proportions was found in one of 36 tests (i.e. combinations of sample and variable locus), namely for $L d h-5$ in the sample of anadromous Brown Trout from site E [Vithayasai's (1973) exact test; $P=0.010$ ], where we detected a deficiency of heterozygotes. It is possible that anadromous Brown Trout were sampled from two or more genetically different populations at site $\mathrm{E}$, but one significant deviation among the number of tests involved may well represent a statistical type I error.

Table 2 Allele frequency distribution (variant alleles only) for Brown Trout in the Voss River system, Norway. $N=$ number of fish, $H=$ average heterozygosity, $\mathrm{L}=$ landlocked, $\mathrm{P}=$ parr, $\mathrm{R}=$ resident, $\mathrm{A}=$ anadromous. Map codes refer to Fig. 2

\begin{tabular}{|c|c|c|c|c|c|c|c|c|c|c|c|}
\hline \multirow{2}{*}{$\begin{array}{l}\text { Map } \\
\text { code }\end{array}$} & \multirow[b]{2}{*}{ Tributary } & \multirow[b]{2}{*}{ Morph } & \multirow[b]{2}{*}{$N$} & \multirow{2}{*}{$\begin{array}{l}\text { Aat }-3^{*} \\
(50)\end{array}$} & \multicolumn{2}{|l|}{$A g p-2$} & \multirow{2}{*}{$\begin{array}{l}C p k-1 \\
(115)\end{array}$} & \multirow{2}{*}{$\begin{array}{l}L d h-5 \\
(105)\end{array}$} & \multirow{2}{*}{$\begin{array}{l}M d h-2 \\
(125)\end{array}$} & \multirow{2}{*}{$\begin{array}{l}\text { Pgi-2 } \\
(130)\end{array}$} & \multirow[b]{2}{*}{$H(\% ; 40$ loci $)$} \\
\hline & & & & & $(25)$ & $(50)$ & & & & & \\
\hline A & Fiksno & $\mathbf{L}$ & 100 & 0.035 & 0 & 0.030 & 0.025 & 0.855 & 0.035 & 0 & 1.2 \\
\hline B & Gryteelvi & $\mathbf{L}$ & 50 & 0 & 0 & 0 & 0 & 0.940 & 0 & 0 & 0.3 \\
\hline $\mathrm{C}$ & Langejolo & $\mathrm{L}$ & 50 & 0 & 0.020 & 0 & 0 & 0.950 & 0 & 0 & 0.3 \\
\hline D & Dyrvo & $\mathrm{P}$ & 40 & 0.400 & 0 & 0.138 & 0.050 & 0.088 & 0.150 & 0 & 3.1 \\
\hline D & Dyrvo & $\mathrm{R}$ & 106 & 0.412 & 0 & 0.085 & 0.071 & 0.038 & 0.156 & 0.009 & 2.8 \\
\hline D & Dyrvo & A & 65 & 0.378 & 0 & 0.138 & 0.077 & 0.062 & 0.115 & 0.015 & 3.0 \\
\hline $\mathrm{E}$ & Teigdalselvi & $\mathrm{R}$ & 42 & 0.205 & 0 & 0.107 & 0.095 & 0.155 & 0.298 & 0.012 & 3.5 \\
\hline $\mathrm{E}$ & Teigdalselvi & A & 20 & 0.194 & 0 & 0.150 & 0.025 & 0.125 & 0.250 & 0 & 3.0 \\
\hline
\end{tabular}

*Aat-3 was scored for 134 fish from site D and 57 fish from site E. 


\section{Genetic differentiation}

The genetic relationships among the various lifehistory types of Brown Trout in the Voss River system were quantified by cluster and gene diversity analyses. The dendrogram resulting from the cluster analysis (Fig. 3) reveals a major branch distinguishing the landlocked Brown Trout (sites A, B and C), from Brown Trout at sites $\mathrm{D}$ and $\mathrm{E}$ (irrespective of life-history type).

Coexisting life-history types cluster tightly together in two sub-branches, each one representing a locality within the accessible part of the Voss River system (parr, resident and anadromous Brown Trout at site D, and resident and anadromous Brown Trout at site E).

The genetic relationships depicted by the dendrogram reflect the pattern of allelic variation revealed by Table 2, where Aat-3, Agp-2, Mdh-2 and Pgi-2 are close to fixation for the 100 -allele in the three samples of landlocked Brown Trout (sites A, B and C) while being highly polymorphic in the accessible localities further downstream. Moreover, a higher frequency of $L d h-5(105)$ is found among the landlocked Brown Trout. Further inspection of Table 2 shows that among the accessible sites $\mathrm{D}$ and $\mathrm{E}$, differences in allele frequencies occur between sites at Aat-3,Ldh-5 and $M d h-2$, but not between life-history types within sites.

The hierarchical gene diversity analysis (Table 3 ) compares the proportional contribution of various sources of variation to the total gene diversity in the material (excluding the parr from site D). Of the total gene diversity 34 per cent is explained by genetic differences between samples, 32 per cent of which results from differences between landlocked and accessible localities. Additional significant heterogeneity $(<2$ per cent) is attributable to differences between localities within each of the two parts of the drainage system (landlocked and accessible), whereas no significant heterogeneity results from differences beween life-history types within localities. A hierarchical $G$-test demonstrates that these results are consistent across loci (Table 3).

\section{Life-history variation}

The variability pattern for the natural tip length among Brown Trout spawners from the Voss River system differs markedly from that shown by the gene diversity analysis. Variance component analysis of length data shows that 78 per cent of the total variance in length is attributable to differences between resident and anadromous life-history types. Additional significant heterogeneity results from differences between landlocked and accessible localities ( 11 per cent), and from females being slightly but consistently larger than males ( 2 per cent). No significant heterogeneity results from length variation between localities within either the landlocked or accessible localities.

The sex ratio is much more skewed towards males in the resident Brown Trout than in the coexisting anadromous Brown Trout (Fisher's exact text; $P<0.001$ at both site $\mathrm{D}$ and $\mathrm{E})$ or in the landlocked Brown Trout $(P<0.001)$. In fact, no mature female was found among 42 resident Brown Trout from site $\mathrm{E}$, and only 3 out of 107 residents from site D were female.

\section{Discussion}

Ecological and morphological studies have not settled the discussion about genetic relationships between the two most widely known life-history types of Brown Trout, namely resident and anadromous (Sea Trout) types. Several studies suggest that they are conspecific

Genetic distance

0.02

$0.01+0$

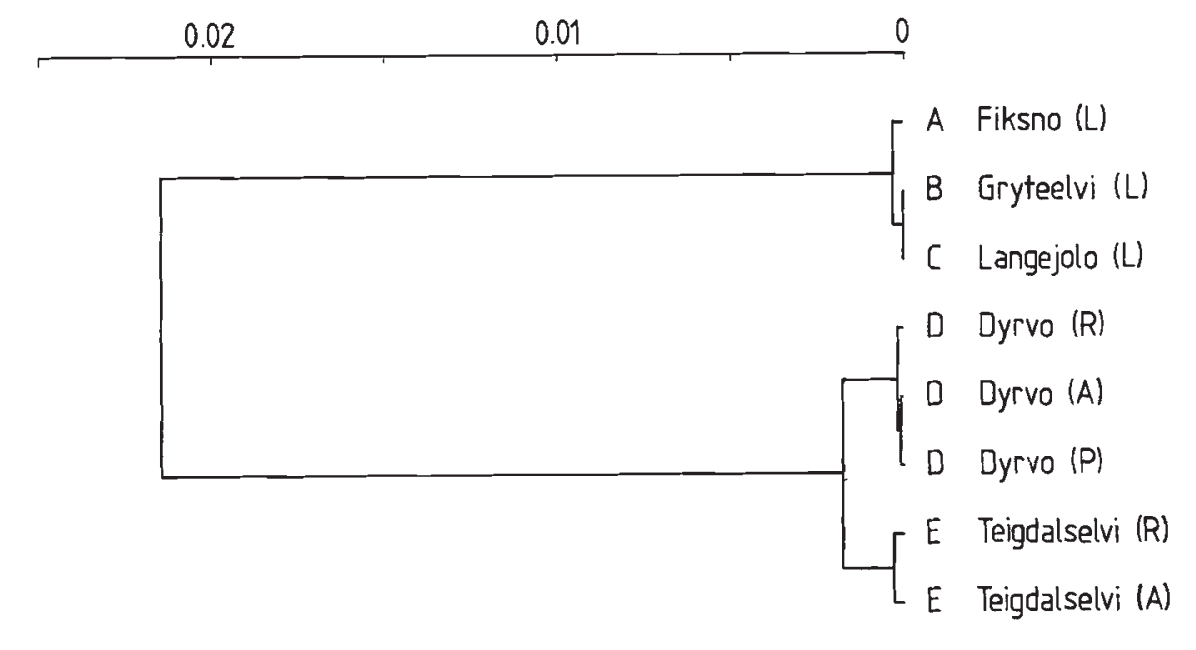

Fig. 3 Dendrogram to summarize the genetic relationships between lifehistory types and populations sampled. The dendrogram is constructed by the UPGMA algorithm from Nei's genetic distance, and is based on 40 loci.

$\mathrm{A}=$ anadromous Brown Trout, $\mathrm{L}=$ landlocked Brown Trout, $\mathrm{P}=$ parr, and $\mathrm{R}=$ resident Brown Trout. Map codes refer to Fig. 2. 
Table 3 Distribution of electrophoretically detected gene diversity among landlocked, resident and anadromous life-history types of Brown Trout from the Voss River system, Norway

\begin{tabular}{|c|c|c|c|c|c|c|}
\hline \multirow[b]{2}{*}{ Locus } & \multicolumn{3}{|c|}{ Absolute gene diversity } & \multicolumn{3}{|c|}{ Relative gene diversity $\left(G_{\mathrm{ST}} ; \%\right)$ between samples } \\
\hline & $\begin{array}{l}\text { Total } \\
\left(H_{\mathrm{T}}\right)\end{array}$ & $\begin{array}{l}\text { Within samples } \\
\left(H_{\mathrm{S}}\right)\end{array}$ & $\begin{array}{l}\text { Between samples } \\
\left(D_{\mathrm{ST}}\right)\end{array}$ & $\begin{array}{l}\text { Between upper } \\
\text { (landlocked) } \\
\text { and lower regions }\end{array}$ & $\begin{array}{l}\text { Between sites } \\
\text { within regions }\end{array}$ & $\begin{array}{l}\text { Between life- } \\
\text { history types } \\
\text { within sites }\end{array}$ \\
\hline Aat -3 & 0.289 & 0.237 & 0.052 & $13.8^{* * *}$ & $3.9^{* * *}$ & 0.1 \\
\hline$A g p-2$ & 0.140 & 0.134 & 0.006 & $4.0^{* * *}$ & $1.9^{*}$ & 0.5 \\
\hline Cpk-1 & 0.080 & 0.078 & 0.002 & $2.1^{* * *}$ & 0.2 & 0.9 \\
\hline$L d h-5$ & 0.494 & 0.161 & 0.333 & $66.6^{* * *}$ & $0.8^{* * *}$ & 0.0 \\
\hline$M d h-2$ & 0.214 & 0.190 & 0.024 & $8.5^{* * *}$ & $2.7 * * *$ & 0.3 \\
\hline Pgi-2 & 0.010 & 0.010 & 0.000 & $0.4^{*}$ & 0.1 & 0.2 \\
\hline Average & 0.031 & 0.020 & 0.011 & $32.1^{* * *}$ & $1.7^{* * *}$ & 0.2 \\
\hline S.E. & 0.015 & 0.009 & 0.009 & 17.1 & 0.7 & 0.1 \\
\hline
\end{tabular}

A hierarchical $G$-test was used to test allele frequency differences at each level of comparison: ${ }^{*} P<0.05, * * P<0.01$, *** $P<0.001$, otherwise not significant.

(Dahl, 1910; Frost \& Brown, 1967) and that they may even belong to the same population (Campbell, 1977; Jonsson, 1982, 1985), although Nall (1930), in his book on Sea Trout, argued to the contrary.

Rearing and tagging studies have shown that freshwater resident individuals can develop from anadromous parents, and vice versa (Skrochowska, 1969). Resident behaviour appears to be associated with slow growth during the young (parr) stage. Skrochowska (1969) did not, however, consider resident and anadromous Brown Trout to belong to the same population because artificially produced offspring of either type differed markedly in migration tendency (i.e. proportions of resident and anadromous individuals) and offspring from crosses beween resident and anadromous trout had an intermediate migration tendency. Jonsson (1982) showed a difference in migration tendency between Brown Trout from above (among landlocked trout) and below a waterfall (Lake Vangsvatnet; Fig. 2) in the Voss River system. This between-population difference seems not to be due to environmental factors, but rather to genetic differences probably resulting from a strong selection pressure for maintenance of position in the river above the waterfall (Jonsson, 1982). On the other hand, whether or not a fish migrated within the population from below the waterfall seemed to a large extent to be determined by differences in individual growth rate, to which there is a strong environmental component (Jonsson, 1985). Parallel results have been obtained for other salmonid species, including Sockeye Salmon (Ricker, 1938) and Arctic Char (Nordeng, 1983).
In all the above-mentioned species it has been noted that males predominate among the resident spawners and females among the anadromous ones (Dahl, 1910; Ricker, 1938; Nordeng, 1983). This can be directly related to the greater tendency of males to show resident behaviour, and suggests that resident and anadromous individuals may be components of the same population (Svärdson \& Anheden, 1963; Campbell, 1977; Jonsson, 1985). In the material presented here, males also predominated in the anadromous trout from site D and in the landlocked populations. This reflects the higher activity of males on the spawning grounds; samples from throughout the year in the same localities reveal a predominance of females among anadromous trout, and a sex ratio close to unity in the landlocked populations (Jonsson, 1989).

Morphological and ecological traits that are subjected to environmental variation cannot unequivocally delineate the genetic relationships within and between fish species (Allendorf et al., 1987; Avise, 1989; and references therein). Population genetic information, based on studies of loci that are neutral or nearly neutral to selection, is necessary to reveal the underlying genetic population structure (Ryman, 1983). The genetic studies reported here show that within the Voss River system, geographical variation is the strongest determinant of genetic differentiation in the Brown Trout. A major dichotomy occurs between landlocked Brown Trout and Brown Trout from the lower reaches of the Voss River system. There may be several reasons for this dichotomy. It is probably due to the bottleneck effect resulting from there being only a 
few trout founding the currently existing landlocked populations, whether they were natural immigrants or transplanted by man. The low heterozygosity in the landlocked populations is consistent with this explanation (cf. Crow \& Kimura, 1970).

Genetic differences between resident and anadromous Brown Trout sampled at separate locations within the same watercourse have led some authors (e.g. Skaala \& Nævdal, 1989) to conclude that resident and anadromous Brown Trout per se belong to genetically different populations. Our analyses show that given that the effects of life history and spawning location can be separated, there are larger genetic differences between Brown Trout spawning in different localities than between different life-history types spawning in the same localities. This conclusion is in accordance with studies over a broad geographical range showing no overall genetic dichotomy between landlocked and anadromous populations of Brown Trout (Ryman, 1983; Ferguson, 1989).

Approaches to the problem of life-history (or ecological) polymorphism in salmonids, along the same lines as in the present paper, have been applied to the occurrence of coexisting dwarf- and normal-sized Arctic Charr (Hindar et al., 1986), and of coexisting anadromous and lake-resident Sockeye Salmon (Foote et al., 1989). Both studies reached conclusions similar to ours, namely, that genetic differences between different morphotypes of a salmonid species are minor relative to the genetic differences between populations from separate locations, even for locations in close geographical proximity. This is not to say that different life-history types occurring sympatrically may never belong to separate populations (see e.g. Allendorf et al., 1976; Kirkpatrick \& Selander, 1979; Ryman et al., 1979; Ferguson \& Mason, 1981; Hindar et al., 1986; Ferguson, 1989; Foote et al., 1989; Verspoor \& Cole, 1989), but rather, that genetic differentiation and lifehistory polymorphism may occur independently in salmonid fishes (Hindar et al., 1986). In conclusion, there is no evidence that coexisting life-history types represent different evolutionary lineages in the Brown Trout or in any other salmonid species.

The precise homing behaviour of Brown Trout (Stuart, 1957) and other salmonids (Quinn \& Tallman, 1987) predisposes for the development of genetically different, local populations in different spawning areas. These populations may differ according to local environmental variation with respect to proportions of resident and anadromous individuals (Jonsson, 1985; Elliott, 1989) and other life-history traits such as size and age at smoltification and maturation (L'Abée-Lund et al., 1989). For example, the presence of a lake in the nursery area (e.g. site D) seems to be important for the development of resident individuals within either sex in a number of salmonid species, otherwise only males become resident, as in site $\mathrm{E}$.

Assortative mating by life-history type is probably necessary for reproductive isolation to develop in sympatry (Foote \& Larkin, 1988). We suggest that the sex ratio within both types must probably be close to $1: 1$ for assortative mating to be a viable strategy. Studies of the spawning population in Dyrvo River (D) suggest that the resident part consists of several hundred males and only about 10 female spawners annually (K. Hindar \& B. Jonsson, unpublished results). It is likely that resident males in such a situation will gain more from trying to fertilize eggs of anadromous females (e.g. Gross, 1985) than to mate assortatively with resident females.

These are speculative comments on the possibility for concurrent evolution of life-history polymorphism and reproductive isolation in salmonid fishes. At this point it should be stressed that although we cannot adequately explain why different life-history types occur within the same population in some cases and are separate in others, there is enough evidence from a number of species to conclude that intraspecific genetic differentiation is greater by locality than by life-history type in salmonids (Ryman, 1983; Hindar et al., 1986; Ståhl, 1987; Foote et al., 1989; this paper).

\section{Acknowledgements}

We would like to thank Finn R. Gravem, Ørnulf Haraldstad, Dag Matzow, Odd Terje Sandlund, Tormod A. Schei and Leif M. Sættem for their help in collecting the material, Ulla Saedén for help in the laboratory, and Finn Økland for help with the plotter. Per Erik Jorde and Fred Utter gave valuable comments on a previous draft of the manuscript, and Veronica Phillips Olsen kindly corrected the language. The Norwegian Institute for Nature Research, the University of Oslo, the Municipality of Voss, and the Swedish Natural Science Research Council provided financial support.

\section{References}

ALLENDORF, F. W. AND UTTER, F. M. 1979. Population genetics. In: Hoar, W. S., Randall, D. J. and Brett, J. R. (eds) Fish Physiology, 8, Academic Press, New York, pp. 407-454.

ALLENDORF, F. W., MITCHELL, N., RYMAN, N. AND STÅHL, G. 1977. Isozyme loci in brown trout (Salmo trutta L.): Detection and interpretation from population data. Hereditas, 86, $179-190$.

ALLENDORF, F. W., RYMAN, N., STENNEK, A. AND STÅHL, G. 1976. Genetic variation in Scandinavian brown trout (Salmo 
trutta L.): Evidence of distinct sympatric populations. Hereditas, 83, 73-82.

ALLENDORF, F. W., RYMAN, N. AND UTTER, F. M. 1987. Genetics and fishery management: past, present, and future. In: Ryman, N. and Utter, F. M. (eds) Population Genetics and Fishery Management, University of Washington Press, Seattle, pp. $1-19$.

AVISE, J. C. 1989. A role for molecular genetics in the recognition and conservation of endangered species. Trends Ecol. Evol., 4, 279-281.

BALON, E. K. (ed.) 1980. Charrs, Salmonid Fishes of the Genus Salvelinus. Dr W. Junk, The Hague.

BEHNKE, R. J. 1972. The systematics of salmonid fishes of recently glaciated lakes. J. Fish. Res. Board Can., 29, 639-671.

CAMPBELL, J. S. 1977. Spawning characteristics of brown trout and sea trout Salmo trutta L. in Kirk Burn, River Tweed, Scotland. J. Fish Biol., 11, 217-229.

CAMPTON, D. E. AND UTTER, F. M. 1987. Genetic structure of anadromous cutthroat trout (Salmo clarki clarki) in the Puget Sound area: evidence for restricted gene flow. Can. J. Fish. Aquat. Sci., 44, 573-582.

CHAKRABORTY, R., HAAG, M., RYMAN, N. AND STÅHL, G. 1982. Hierarchical gene diversity analysis and its application to brown trout population data. Hereditas, 97, 17-21.

CROW, J. F. AND KIMURA, M. 1970. An Introduction to Population Genetics Theory. Harper and Row, New York.

DAHL, K. 1910. Alder og vekst hos laks og orret belyst ved studier av deres skael. Kristiania, Norway. English translation. 1911. The age and growth of salmon and trout in Norway as shown by their scales. Salmon and Trout Association, London.

ELlioTT, J. M. 1989. Growth and size variation in contrasting populations of trout Salmo trutta: an experimental study on the role of natural selection. J. Anim. Ecol., 58, 45-58.

FERGUSON, A. 1989. Genetic differences among brown trout, Salmo trutta, stocks and their importance for the conservation and management of the species. Freshwat. Biol., 21, 35-46.

FERGUSON, A. AND MASON, F. M. 1981. Allozyme evidence for reproductively isolated sympatric populations of brown trout Salmo trutta L., in Lough Melvin, Ireland. J. Fish Biol., 18, 629-642.

FOOTE, C. J. AND LARKIN, P. A. 1988. The role of male choice in the assortative mating of anadromous and non-anadromous sockeye salmon (Oncorhynchus nerka). Behaviour, 106, 43-62.

FOOTE, C. J., WOOD, C. C. AND WITHLER, R. E. 1989. Biochemical genetic comparison of sockeye salmon and kokanee, the anadromous and nonanadromous forms of Oncorhynchus nerka. Can. J. Fish. Aquat. Sci., 46, 149-158.

Frost, w. E. AND BRown, M. E. 1967. The Trout. Collins, London.

GROSs, M. R. 1985. Disruptive selection for alternative life histories in salmon. Nature, 313, 47-48.

HINDAR, K., RYMAN, N. AND STAHL, G. 1986. Genetic differentiation among local populations and morphotypes of Arctic charr, Salvelinus alpinus. Biol. J. Linn. Soc., 27, 269-285. Jonsson, B. 1982. Diadromous and resident trout Salmo trutta: is their difference due to genetics? Oikos, 38, 297-300.

JONSSON, B. 1985. Life history patterns of freshwater resident and sea-run migrant brown trout in Norway. Trans. Am. Fish. Soc., 114, 182-194.

JONSSON, B. 1989. Life history and habitat use of Norwegian brown trout (Salmo trutta). Freshwat. Biol., 21, 71-86.

KIRKPATRICK, M. AND SELANDER, R. K. 1979. Genetics of speciation in lake whitefishes in the Allegash basin. Evolution, 33, 478-485.

KORNFIELD, I., BELAND, K. F., MORING, J. R. AND KIRCHEIS, F. 1981. Genetic similarity among endemic Arctic char (Salvelinus alpinus) and implications for their management. Can. J. Fish. Aquat. Sci., 38, 32-39.

KRUEGER, C. C. AND MAY, B. 1987. Stock identification of naturalized brown trout in Lake Superior tributaries: differentiation based on allozyme data. Trans. Am. Fish. Soc., $116,785-794$.

LABEEE-LUND, J. H., JONSSON, B. AND JENSEN, A. et al. 1989. Latitudinal variation in life-history characteristics of sea-run migrant brown trout Salmo trutta. J. Anim. Ecol., 58, 525-542.

NALL, G. H. 1930. The Life of the Sea Trout. Seeley, London. NEI, M. 1975. Molecular Population Genetics and Evolution. North-Holland, New York.

NORDENG, H. 1983. Solution to the char problem based on Arctic char (Salvelinus alpinus) in Norway. Can. J. Fish. Aquat. Sci., 40, 1372-1387.

QUINN, T. P. AND TALLMAN, R. F. 1987. Seasonal environmental predictability and homing in riverine fishes. Environ. Biol. Fish., 18, 155-159.

RICKER, w. E. 1938. 'Residual' and kokanee salmon in Cultus Lake. J. Fish. Res. Board Can., 4, 192-218.

RICKER, W. E. 1972. Hereditary and environmental factors affecting certain salmonid populations. In: Simon, R. C. and Larkin, P. A. (eds) The Stock Concept in Pacific Salmon, H. R. MacMillan Lectures in Fisheries, University of British Columbia Press, Vancouver, pp. 19-160.

RYMAN, N. 1983. Patterns of distribution of biochemical genetic variation in salmonids: differences between species. Aquaculture, 33, 1-21.

RYMAN, N., ALLENDORF, F. W. AND STÅHL, G. 1979. Reproductive isolation with little genetic divergence in sympatric populations of brown trout (Salmo trutta). Genetics, 92, 247-262.

SCOTT, w. B. AND CROSSMAN, E. J. 1973. Freshwater fishes of Canada. Bull. Fish. Res. Board Can., 184, 1-966.

SKAALA, ø. AND NAEVDAL, G. 1989. Genetic differentiation between freshwater resident and anadromous brown trout, Salmo trutta, within watercourses. J. Fish Biol., 34, 597-605.

SKROCHOWSKA, s. 1969. Migrations of the sea-trout (Salmo trutta L.), brown trout (Salmo trutta m. fario L.) and their crosses. Pol. Arch. Hydrobiol., 16, 125-192.

SNEATH, P. H. A. AND SOKAL, R. R. 1973. Numerical Taxonomy. W. H. Freeman, San Francisco.

SOKAL, R. R. AND ROHLF, F. J. 1981. Biometry, 2nd edition. W. H. Freeman, San Francisco.

STÅHL, G. 1987. Genetic population structure of Atlantic 
salmon. In: Ryman, N. and Utter, F. M. (eds) Population Genetics and Fishery Management, University of Washington Press, Seattle, pp. 121-140.

STUART, T. A. 1957. The migration and homing behaviour of brown trout (Salmo trutta L.). Freshwater Salmon Fish. Res., 18, 1-27.

SVÄRDSON, G. AND ANHEDEN, H. 1963. Könskvot och utvandring hos Verkeåns öring. Svensk Fiskeri Tidskrift, 72, 165-169. (In Swedish.)

TAGGART, J., FERGUSON, A. AND MASON, F. M. 1981. Genetic variation in Irish populations of brown trout (Salmo trutta L.): electrophoretic analysis of allozymes. Comp. Biochem.
Physiol., 69B, 393-412.

UTTER, F. M., HODGINS, H. O. AND ALLENDORF, F. W. 1974. Biochemical genetic studies of fishes: potentials and limitations. In: Malins, D. C. and Sargent, J. R. (eds) Biochemical and Biophysical Perspectives in Marine Biology, Academic Press, New York, pp. 213-238.

VERSPOOR, E. AND COLE, L. J. 1989. Genetically distinct populations of resident and anadromous Atlantic salmon, Salmo salar. Can. J. Zool., 67, 1453-1461.

VITHAYASAI, C. 1973. Exact critical values of the HardyWeinberg test statistic for two alleles. Commun. Stat., 1, 229-242. 